bodies-the World Health Organisation and Unesco. The president of the World Federation, Dr. J. R. Rees (Great Britain), has expressed the hope that this consultative arrangement will lead to a further recognition of the importance of montal health in efforts to establish a healthier and happier world society. Dr. Rees also announced that the Federation has accepted the invitation of Unesco to send an observer to its general conference which opened at Beirut on November 17. The Federation is being represented by Dr. M. K. el Kholy, of Egypt, the member for the African Continent on the Executive Board.

The World Federation already comprises twentyone mental health associations of different nations, and others are expected to be admitted to membership in the near future. Dr. André Repond, of Switzerland, now vice-president, in accordance with the by-laws of the Federation, will succeed Dr. Rees as president next year. Prof. H. C. Rümke, of Holland, is chairman of the Executive Board, which will meet in Amsterdam in January. Arrangements are also now being made for the Assembly of the World Federation to be held in Geneva next August, when delegates from all over the world will be present.

\section{P. F. Frankland Memorial Lecture}

THE Birmingham and Midlands Section of the Royal Institute of Chemistry is endeavouring to collect $£ 1,500$ to establish a memorial lecture in honour of Percy Faraday Frankland, who occupied the Mason chair of chemistry in the University of Birmingham with great distinction during 1894-1918 and who died two years ago. The lectures will be delivered in Birmingham at intervals of three to four years and will deal mainly with original work; they will be published and may be expected to make a notable contribution to chemical literature. All money subscribed goes to the endowment; cheques drawn in favour of "P. F. Frankland Memorial Lecture", crossed a/c payee, should be sent to Mr. E. M. Joiner (secretary, Birmingham and Midlands Section, Royal Institute of Chemistry), 15 Halton Road, Sutton Coldfield, Warwickshire.

\section{Lantern Slides of Diagrams, Formulæ, etc.}

Is Nature of June 29, 1946, p. 879, and several earlier issues, correspondents described methods they had used successfully for writing on glass. Mr. E. H. Leach, University Laboratory of Physiology, Oxford, states that any ink to which a drop or two of a solution of a synthetic detergent ('Teepol' type) has been added can be used for writing on any clean glass surface. Indian ink appears to be the most suitable. Some proprietary brands of ink appear to contain synthetic detergent and require no further addition. Glassware and microscope slides can be marked with such inks.

\section{Hawaiian Libraries}

MANY people are unaware that excellent libraries exist in Hawaii in conjunction with that country's museums, university, research institutions and archives of the Government. For information on the holdings of these libraries a "Union List of Serials in Hawaii" is being prepared; the Committee on the Union List, Hawaii Library Association, Honolulu, Territory of Hawaii, invites pre-publication orders at 6 dollars a copy.

\section{Conference on Organised Information Services}

THE Northern Branch of Aslib has arranged a conference on the general theme of the value of organised information service to industry, commerce and education, to be held at the North of England Institute of Mining and Mechanical Engineers, Neville Hall, Westgate Road, Newcastle-upon-Tyne, on December 7. The chair will be taken by R. Trevor Jenkins, technical manager, Vickers-Armstrongs, Ltd., Elswick and Scotswood Works, Newcastleupon-Tyne. The conference will be opened at 10 a.m. by the Lord Mayor of Newcastle-upon-Tyne. Dr. V. E. Parke will speak on "Intelligence: Some Fundamental Principles", and will be followed by Mr. E. Austin Hinton on "Industrial, Technical and Commercial Information: The Contribution of the Public Library". In the afternoon session, at 2.30 p.m., Mr. R. O. MacKenna will speak on "Information Service from the point of view of the Universities", and will be followed by Mr. T. S. Nicol, who will deal with the point of view of professional associations. Miss J. Scurfield will speak on "The Regional Library Bureaux" ; Miss E. M. R. Ditmas will deal with the work of Aslib, and Mr. R. Brightman with that of the Northern Branch. Conference tickets can be obtained (5s. each) from the local organising secretary, Mr. M. G. Cahill-Byrne, Vickers-Armstrongs, Ltd., Elswick Works, Newcastle-upon-Tyne, 4.

\section{Comet 1948 I}

Dr. R. D'E. Atkinson, who led the Royal Observatory eclipse expedition, cabled confirmation of a bright comet seen in the southern sky early in November. During the eclipse on November 1 a photograph showed that the comet was $1^{\circ} 33^{\prime}$ from the centre of the sun, and it was then very bright with a tail. It has been seen in different parts of the southerm hemisphere since then. Its brightness has been estimated as mag. 2. Its daily motion is approximately $-8 \cdot 1 \mathrm{~m}$. in R.A. and $-51^{\prime}$ in declination. It is doubtful whether it will be seen from the British Isles. The latest description from the Cape Observatory states that the object is diffuse with central condensation or nucleus, and that the tail exceeds $1^{\circ}$ in length; hence some of the Press reports about the length of the tail were probably exaggerated.

The Royal Observatory, Cape Town, has communicated the following parabolic orbit and ephemeris computed by Hirst and Stoy :

$$
\text { Elements }
$$

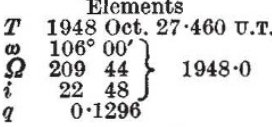

$$
\begin{aligned}
& \text { Ephemeris } \\
& \text { Oh. U.T. }
\end{aligned}
$$

\begin{tabular}{|c|c|c|}
\hline $\begin{array}{r}1948 \\
\text { Nov. } 14 \\
18 \\
22 \\
26\end{array}$ & 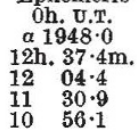 & $\begin{array}{r}\delta 1948 \cdot 0 \\
-25^{\circ} 53^{\prime} \\
2840 \\
3104 \\
3257\end{array}$ \\
\hline
\end{tabular}

\section{Announcements}

THE following higher degrees have been conferred by the University of Aberdeen: Ph.D., on G. F. Walker, for a thesis on "The Clay Mineralogy of some Aberdeenshire Soils" ; M.D., on H. MeL. Raffan, for a thesis on "Poliomyelitis in Aberdeenshire".

Erratum. Dr. Oscar Hechter states that the reference in the communication "Spreading Phenomenon and Inflammation" (Nature, October 30, p. 701) to earlier work (par. 4) should be to footnote 1, and not footnote 2 as appeared in his manuscript. 